\title{
Foreign Direct Investment in China Manufacturing Industry - Transformation from a Low Tech to High Tech Manufacturing
}

\author{
Kelly Liu \\ School of Economics and Finance, Campbelltown Campus \\ University of Western Sydney \\ Locked Bag 1797, Penrith NSW 2751, Australia \\ Tel: 61-2-4658-0745Ｅ-mail: k.liu@uws.edu.au \\ Kevin Daly (Corresponding author) \\ School of Economics and Finance, Campbelltown Campus \\ University of Western Sydney \\ Locked Bag 1797, Penrith NSW 2751, Australia \\ Tel: 61-2-4658-0745 E-mail:k.daly@uws.edu.au
}

Received: January 21, 2011 Accepted: February 11, $2011 \quad$ doi:10.5539/ijbm.v6n7p15

\begin{abstract}
Since China opened its economy to foreign investment in 1979, it has become the second largest Foreign Direct Investment (FDI) destination in the world after USA. Over the period 1997 to 2008, the manufacturing sector has dominated China's FDI inflow, however, when manufacturing activity is bifurcated into low and high technology classes, it becomes evident that China is in a transition stage moving from FDI in traditional low-tech activity to a high-tech manufacturing environment. This paper attempts to summarise and explain the key determinants of FDI inflow across low and high technology manufacturing industry across three geographical regions of China. In the paper we empirically investigate the determinants of FDI high-low tech inflow by market size, labour cost, labour quality, and infrastructure. We also investigate the theoretical foundations for China's transition from a low tech to a high tech manufacturing environment.
\end{abstract}

Keywords: China, FDI, Manufacturing industry, Low high technology

\section{Introduction}

Since China reformed and adopted 'open up' policies in 1979, Foreign Direct Investment (FDI) increased dramatically, from US\$ 1.23 billion in 1986 to US\$92.40 (Note 1) billion in 2008. In terms of aggregate FDI, China became the largest destination of FDI inflow among developing nations since 1992(Note 2), and the second largest in the world following the US in recent years. Comparing the composition of FDI inflow to China (Note 3), foreign investors tend to invest proportionately more in secondary sector (Manufacturing) rather than primary (Agriculture) and tertiary (Service) sectors. Indeed, the secondary sector received more than 60 percent of total utilised FDI inflow between 1997 and 2008. By contrast, the primary sector only received 1.5 percent of total utilised FDI (Table.1). The largest portion of FDI goes to manufacturing industry due in part to the supply of cheap labour and the relative low cost of materials. However, little research has been done on identifying the specific sectors where growth actually occurs especially in highlighting output by the degree of technology intensity. With adopted foreign capital, management know-how, trained labour and technology spill over effects, China possesses the capacity to adopt high technology intensive manufacturing industry, especially in the chemical, machinery, and electronic and telecommunication industries.

\section{Table 1 Here}

\section{Transformation from a Low Tech to High Tech Manufacturing}

China is a major exporter of manufactured product around the world, however, as Table 2 shows, in the early stages of openness, with less developed industrial productivity and few foreign investors, exports of manufacturing goods only accounted for 50 per cent of total national exports, with the primary sector accounting for the other half. Since 1990, China introduced several preferential foreign investment policies, which inturn attracted more foreign investors to China, bringing with them advanced technology and management skills. This resulted in the total share of manufactured exports increasing from 74.4 percent in 1990 to 94.6 percent in 2008. Amongs the total exports of manufacturing goods, export of low technology goods (Light and Textile Industrial Products, Rubber Products, Minerals Metallurgical Products) increased from US\$12.57 billion in 1990 to US\$262.39 billion in 2008. However, the share of low technology manufacturing goods in total export of 
manufacturing goods decreased from 27.2 percent in 1990 to 19.4 percent in 2008 . Over the same period, we observe that the total export of high technology manufacturing goods (Chemicals and Related Products and Machinery and Transport Equipment) is increasing in both absolute value term and percentage term. For example, the total export of machinery and transport equipment and chemicals and related products accounted for 20.2 percent of total manufacturing goods in 1990, by 2008, the share increased to 55.7 percent (Note 4). This change in the composition of Chinas manufactured exports from a low to high technology intensity needs to be explained in terms of identifying the factors responsible for such a dramatic turnaround in such a relative short timeframe.

\section{Geographical Distribution of FDI}

Table 2 Here

We begin our investigation by providing a geographical breakdown of China's FDI inflow into 3 regions namely; coastal, inner and western (Note 5), across these regions we observe that FDI inflows are distributed unevenly. Between 1980 and 1988, in an effort to attract foreign capital, four Special Economic Zones (SEZs) (Note 6) and 14 National Economic and Technology Development Zones (NETDZ) (Note 7) were established in the coastal region. Consequently, by 1990, the percentage of total FDI inflow into costal region was 94.4 percent of the entire FDI inflow, while inner and western regions attracted 2.2 and 3.4 percent of total FDI inflow respectively (Figure 1). Faced with the issue of income disparity, the central government in 2000 implemented the 'Go West' policy, in which, the State Council ratified inner and western regions to set up NETDZs to attract FDI and reduce regional disparity. Although this has not affected coastal region's dominance in total FDI inflow, it has however, resulted in a 8.9 percentage reduction during the eight years period (from 87.9 percent in 2000 to 79.0 percent in 2008). During the same period, the inner region nearly doubled its share of total FDI inflow (17.1 percent in 2008 compared to 9.3 percent in 2000), while western region also saw a significant increase in its share of the Chinese FDI pie, from 2.8 percent in 2000 to 6.1 percent in 2008.

\section{Figure 1 Here}

Each region has different strengths and weakness, and specialise in different areas of industrial activity. The coastal region received privileged status which in turn brought forward comparative advantages in infrastructure, capital, technology and management skills; today the coastal region is leading China in high technology and high value added manufacturing activity. As illustrated in Figure 2, coastal region received 77 percent and 91 percent of total FDI in medical product and chemical products manufacturing industries, respectively. By comparison the western region only accounted for 8 and 3 per cent, respectively. In contrast, the western and inner regions are rich with natural resources, but have inadequate capital, infrastructure and technology. Through the continuation of 'Go West' policy, inner and western regions became more developed, with a growing competitive advantage in metal products. By 2009, utilised FDI in metal products manufacturing industry reached US\$ 172.04 million, and western region accounted for nearly 19 percent of total FDI in this industry in China (Figure 3).

\section{Figure 2 Here}

\section{Figure 3 Here}

Since different regions have different chatacteristics in terms of economic development, human resources, government intensity of R\&D development, some regions may attract FDI in high technology manufacturing industry while others may attract FDI in low technology manufacturing industry. This paper investigates a number of factors such as size of economy, labour cost, labour quality, physical and technology infrastructure to explain the pattern of FDI inflow across low and high technology manufacturing industries among three regions. The structure of the paper is as follows: Section 2 provides the defination of high and low technology manufacturing industry. Section 3 indicates the reasons behind the classification of high and low tech manufacturing industry, Sections 4 and 5 provide the theoretical background and empirical evidence, finally Sections 6 presents our conclusion and recommendations.

\section{Definition of High and low-tech manufacturing industry}

The classification of manufacturing industries by the intensity of technology as used in OECD is based on the International Standard Industrial Classification of All Economic Activities (ISIC Rev.3). ISIC Rev.3 classification is an internationally accepted standard for categorising producing units within an economy. Under manufacturing industry, there are 23 divisions, and can be further classified into 61 groups. The OECD classifies 23 divisions into four categories based on technology intensity: high technology; medium-high technology; medium-low technology and low technology. The technology intensity is measured by two indicators: R\&D expenditure divided by value added and R\&D expenditure divided by production. Industries ranked in higher technology category have higher research intensity indicators compared to industries in lower category.

With continuing open up, in order to increase international comparison and information communication, China adopted the 'Industrial Classification for National Economic Activities (GB/T475-2002) in 2003. This classification mainly obeys the same principle, methods and industrial classification system as ISIC Rev.3, but with adjustment of some classes' context compare to ISIC. For instance, the manufacturing industry has 30 
divisions and 169 groups in GB/T44754-2002, but in ISIC Rev.3, it is only 23 divisions and 61 groups. Nevertheless, we set up corresponding classes and transit the Chinese manufacturing industry class into ISIC Rev.3 and classify them into different technology categories. For simplicity, this paper only classifies them into low (low and medium-low technology) and high (medium-high and high technology) categories. Low technology category includes manufacture of food, beverages, tobacco textiles, wearing apparel, leather and related products, wood, furniture, paper and paper product, printing and recorded media, coke and refined petroleum, rubber, plastic, non-metallic mineral, fabricated metal products. High technology category includes manufacture of chemicals, pharmaceutical products, general and special purpose machinery, motor vehicles, computer, and electronic equipments. In 2002, the percentage of foreign equity in total national equity in low technology and high technology manufacturing industry were 22.1 and 32.1 per cent, respectively, in 2007, these two shares both increased, and reached to 24.4 and 33.5 percent, respectively.

\section{Why the classification FDI in manufacturing industry}

Manufacturing industry is China's major employer (Zhao, 2004) and also the main channel of for employment growth (MOFTEC, 2010). Before we explain reasons behind breaking up manufacturing industry into low and high technology categories, we provide an overview as to why understanding the importance of FDI in manufacturing industry is essential. Firstly, FDI in manufacturing industry represents 63.2 per cent of total utilised FDI in China during the period 1997- 2008 and reached US\$ 49.89 billion in 2008. Secondly, China is a major exporter of world's total merchandise trade, Foreign Funded Enterprises (FFE) control over half of total manufactured export (Table 3). Indeed, electronic and telecommunications have the highest share of FFE export of total national exports, which is 91.9 percent, and followed by instrument products (87.3 percent), Papermaking and paper products (83.4 percent)printing and record pressing (79.9percent) (China Industrial Economic Statistical Yearbook, 2009).

\section{Table 3 Here}

The classification of FDI in manufacturing industry by its technological intensity is particularly useful for policy makers in China from two perspectives. Firstly, after the world experiencing the most economic downturn since the Great Depression, the demand for commodities has decreased, the traditional export-driven, low labour intensive manufacturing industries have been hit hardest (OECD, 2009), and the international demand for high-technology products has risen as they can have positive effects on productivity and competitiveness when used throughout economy. Consequently, FDI in manufacturing industry in China is more interested in high technology and/or capital intensive rather than traditional low technology and/or high labour intensive manufacturing industry. For instance, the FDI in textile industry decreased from US\$2.11 billion in 2005 to US\$1.39 billion in 2009. On the other hand, FDI in medical and pharmaceutical products industry increased by 43.9 percent to US\$ 0.95 billion, compare with US\$0.66 billion in 2008. Thus, China should attract more high technology manufacturing FDI. Since the determinants of FDI in high and low technology manufacturing are different, for example high technology manufacturing FDI is attracted by labour quality rather than labour cost, one should be cautious in using aggregate data FDI in manufacturing industry due to the fact that more detailed and precise information is necessary for policy makers.

Secondly, FDI provides access to new technology, capital, R\&D facilities and management know-how for a host region which in turn increases economic development. In China, as more than 80 per cent of total FDI went to coastal region in the past two decades, this left the inner and western to share the remaining, many scholars argue that the uneven distribution of FDI is responsible for the widening regional economic development across China (Wei, Yao \& Liu, 2009). In 2000, central government implemented a 'Go West' policy, which encouraged foreign investors invest in inner and western region to reduce economic disparity. The logic is, if FDI is the major contributor of regional disparity, increase FDI in inner and western regions will reduce that disparity. However, different regions have different characteristics in terms of GDP, labour cost, and human resource quality and technology development. For instance, FDI in high technology manufacturing industry may not be attracted to the western region compared to low technology manufacturing as the former has higher requirements in terms of demand for skilled labour. This is argued by Almeida (2010), who finds that skilled labour is needed to adapt and diffuse new technology in host countries when FDI is received in technological innovation industries. However, this is not the case for China and other low-income countries; alternatively, higher level of FDI received is not associated with heightened skills, rather a specialization in low skilled intensive goods. In other word, coastal region with initinal highly trained labour, should focus on attracting FDI in high technology manufacturing industry, while western region, with rich natural resource endowment but unskilled labour, it should focus on low technology manufacturing and achieving high speed economic development by specialization. As a result, we argue that breaking up manufacturing industries into different categories rather than a whole may provide more quality information for policy makers to attract FDI.

\section{Theoretical Background}

Dunning (1988) integrated a variety of theoretical explanations as to why firms should invest operations abroad by drawing on macroeconomic and trade theory along with microeconomic theories of firm behaviour to develop 
what he termed an Ownership Location Internationalisation (OLI) theory. In this framework, he explained why foreign enterprises choose to invest in another country/region by the mode of FDI rather than exporting or liscening. Three advantages must be satisfied. Ownership advantages refer to firm specific advantages, e.g. patents, technical knowledge, management skills and reputation. This kind of advantages can be transferred internationally within a firm but hard to transfer between firms in the same region. Location advantages refer to the motivations that a MNE chooses to producing abroad, they included access to protected market, favourable tax treatments, lower production cost, lower risk, and favourable structure competition. The internalisation advantages arise when a MNE are better off to produce internally, rather than licensing or exporting, these are due to lower transaction costs, minimising technology imitation, maintaining reputation and protect intellectual property. When a MNE has satisfied all three advantages, the MNE will choose FDI, otherwise, will choose exporting or licensing in relation to which advantages it has already.

Dunning (1980) classifies the motivations of FDI into four types: natural resource seeking FDI, market seeking FDI, efficiency seeking FDI and strategic asset or capability seeking FDI (Table 2). Under resource seeking FDI, MNEs invest abroad to acquire natural resources of a higher quality at a lower real cost than could be obtained in their home country(Dunning, 2008), thus possess natural resources, cost minimisation, cheap and well-motivated unskilled or semi-skilled labour, related transport and communication infrastructure are important factors to determine FDI decision. Under market seeking FDI, MNEs invest in a particular country or region to supply goods and service to the market in host country and/or its neighbouring countries or regions. Domestic market-seeking FDI are depended on market size, policy incentives and products distribution channels. The motivations of efficiency seeking FDI are taking advantage of difference in the availability and relative cost of factor in different countries and taking economies of scale and scope between countries with similar economic structures and income level. Finally, strategic asset seeking FDI is motivated by MNE's long-term strategic objectives, which is sustaining or advancing their global competitiveness or weakening their competitors. Table 4 below summarise the determinants of FDI by different motivations.

\section{Table 4 Here}

Foreign investors invest in China's manufacturing industries may be motivated by both market seeking and efficiency seeking. Thus, in this study, market size, labour cost, labour quality, and physical and technology infrastructure are selected as variables in our modelling. Based on our empirical modelling we aim to inform policy makers regard the optimal allocation of future FDI inflows.

\section{Empirical Analysis of the Determinants of FDI Inflows from a Regional Perspective}

As discussed above, FDI in manufacturing industry in China is motivated by both market seeking and efficiency seeking objectives. In this paper, we use the share of FFE sales to total China's sales (Column A) as a measure of the presence of FDI in the domestic market. We also measure (Column B) the share of foreign enterprises exports relative to foreign sales across both high and low-tech products as our measure of the transformation from low to high-tech production.

Over the timeframe from 1995 - 2008 there is a significant change in the proportion of sales from low tech activities to high tech activities (Column A). In particular low tech classified production experiences a decrease from $33 \%$ to $29 \%$ compared to high-tech production which increases from $25 \%$ to $37 \%$ over the same period. It is also evident from the table 5 (Column B) that the share of foreign enterprises exports in total FFE sales decreases significantly greater in low-tech compared to high-tech industrial production. Overall we observe form table 5 (Column $\mathrm{C}$ ) that the share of foreign enterprises exports in total exports from china over the period has increased significantly more in high-tech manufactured products compared to low-tech products.

\section{Table 5 Here}

\section{Size of the Economy}

Market-seeking FDI aims to set up foreign affiliates in host countries to supply goods and services to the local market. This kind of investment maybe undertaken to exploit new markets, thus, market size, market growth rate, and degree of development of host location are very import for market-seeking FDI.The general implication is that the larger the host market, the faster the rate of economic growth, and the more attractive to locate FDI, (Chen \& Kwan, 2000; Javorcik, 2004; Coughlin \& Segev, 2000; Chen, 1992 \& Lin, 2010).

In the past 2 decades, China's economy grew at an average rate of 9 percent. Table 6 shows, coastal region has 43 percent of China's total population, contributed 60 percent of national GDP, however, inner and western region took 57 percent of national population, but only contributed 40 percent of national GDP. The unbalanced economic development also reflected by the purchasing ability among 3 regions. In 1988, the per capita consumption was CNY 974.25 Yuan per year (US\$ 260.94(Note 8)) in coastal region, CNY 634.67 per year (US\$ 170.51) in inner and only CNY506.1 Yuan per year (US\$ 135.97) in western region. The Figure 4 shows, at the earlier stage, the per capita consumption was not that different between three regions, due to the unbalanced economic development, in 2007, the per capita consumption in coastal region increased to RMB 10920.33 Yuan per year (US\$1572.38), doubling the consumption ability compare to inner region (RMB 5902.44 Yuan or US\$776.23) and western regions (RMB 4885.9 or US\$703.50). 


\section{Table 6 Here}

Figure 4 Here

\section{Labour Cost and Labour Quality}

Labour cost is a key determinant in the level of foreign investment, low labour cost effectively reduces production cost, and in turn increases profit. Hence, foreign investment is prone to congregate at locations where low labour cost exists. Having considered the aforementioned, as China is changing from the quality of FDI to quantity of FDI, it is shifting from tradition labour intense industry to advanced manufacturing industry, such as machinery, chemical products and telecommunication products. Thus, higher labour cost will exist as it reflects the quantity of labour. In 1990, the average wages were roughly at the same level among three regions. However, in the past decades, the average wage growth rate is higher in coastal region compare to inner and western regions. The higher average wage volume is also proof that labour quality is higher in coastal compared to inner and western region. Foreign investors set up manufactures in China and train their labour with advanced knowledge, resulting in improve labour quality, and the subsequent wage increase (Figure 5).

\section{Table 6 Here}

\section{Figure 5 Here}

The problem for China's policy makers is to increase expenditure on education and training of labour such that labour develops skills and qualification appropriate for higher value adding productive activities. Total government spending on education beyond the level of secondary schooling has been small in comparison with other nations at similar levels of per capita income and economic development (Heckman, 2005). China's expenditures on education were $2.97 \%$ of GDP and had been below 3\% in most years since 1992, this is far lower than the average of $5.1 \%$ for developed countries. At the national level, the proportion of graduates from college education (undergraduates and TAFE) was 0.05 percent in 1988 and had risen to only 0.07 percent in 1998. Starting from 1999, the Chinese government increased the enrolment of college students sharply; the annual growth rate in graduates between 1999 and 2008 was 21.9 per cent. However, by 2008, the proportions of graduates with bachelar degree or higher was 4.38 (Note 10) in coastal region and 4.78 percent in inner region, while, in the western region, (with nearly 52 per cent of the national population) it was only 3.9 percent (China Statistical Yearbook, 1996-2009).

\section{Physical and Technology Infrastructure}

Infrastructure development is another major determinant of FDI. Adequate and effective transportation can influence a firm's cost and revenue and hence their location decision. The level of infrastructure development of a particular region should positively correlate to FDI. Cheng and Kwan (2000) report that good infrastructure positively influences the location decision of foreign investors in China, Sun et al (2002), similarly report that good infrastructure had a positive effect on FDI inflow into China in the period 1986-1998.

Motivation for FDI differs when evaluating infrastructure development as a determinant when selecting locations for investment. As mentioned above, efficiency seeking FDI might be attracted by infrastructure development more than domestic seeking FDI due to good infrastructure which can significantly reduce a firm's costs. Direct measures of infrastructure include, highway per kilometres, railway per kilometres, number of ports and airports. Foreign MNE's choice of location is strongly influenced by the number of highways, railways, and interior transport waterways, the more sophisticated the infrastructure in proportion to province size, the greater the FDI inflow. Another important variable is the level of telecommunication services. Higher levels of telecommunication services will save time and reduce the cost of information gathering, thus facilitating business activities. In the early days of economic China's transportation and communication infrastructure were poor, but since then governments at various levels have invested heavily in the construction of highway, railway systems and development of electronic communications facilities. (Fleisher, Li \& Zhao, 2010). Local governments in coastal region, particularly in SEZs, upgraded infrastructure in an effort to attract FDI. For example, the development of highway infrastructure corresponds to greater inflow of FDI in the coastal region compared to the inner and western regions, (Cheng and Kwan, 2000).

In recent years, under pressure from market competition, and loss of comparative advantages in labour intensive industries, upgrading China's high-tech industries has been a top priority. Since 1990, foreign investors have attached more importance to the higher technology products, however higher productivity of foreign firm holds only when a sufficient absorptive capability of advanced technologies is available in the host economy (Zhao \& Zhang, 2010). In this paper, the number of universities and R\&D expenditure per GDP are indicators of technology infrastructure. Table 7 indicates that the number of universities in the coastal region was 1074 in 2008, compared to western region with only 429 units. The regional government in coastal region also invested more in R\&D development institutions than inner and coastal regions.

\section{Table 7 Here}

\section{Conclusion}

In this paper, we analysed and summarised the determinants of FDI for both low and high-tech industrial 
production across three regions in China. In the paper we explain the importance of FDI in China's economic development; secondly, we break down manufacturing according to low and high tech categories by research intensity. We then introduced theoretical arguments for the location of FDI. Finally, we combined the classification of manufacturing industry and motivations of FDI to reach the following conclusions. Firstly efficient seeking FDI in China has created a movement from low to high tech manufacturing industry, here we found that efficiency seeking FDI is positively related to labour quality and infrastructure development, but negatively related to labour cost. In China, labour cost is increasing, across coastal region, compared to inner and western regions. Thus, on cost grounds we suggest that traditional high labour intensive efficienty seeking FDI, should shift from coastal region to inland China. As a result, foreign investors can enjoy lower labour cost, this redirection of industrial activity will help balance economic development and help China reduce income disparity between the regions. However, in order to attract more efficiency seeking FDI, inland China should improve its infrastructure development, and specialise in low-tech manufacturing industry. On the other hand, high technology manufacturng industry is more attractive to coastal regions. Here China should continue encouraging this type of FDI into coastal region, as they are far more developed in areas which attract high-tech investment in manufacturing in terms of GDP per capita, infrastructure and labour skills compared to inland China. Improving R\&D and infrastructure will make the coastal region more attractive for foreign capital. China's unequal regional economic development and resultant economic can be balanced by having clear policy directions in place which will employ labour and materials appropriate to the regions endowments.

\section{References}

Abraham, F., Konings, J., \& Slootmaekers, W. (2010). FDI spillover in the Chinese Manufacturing Sector. Economics of Transition, vol.18, no.1, pp: 143-182,

Almeida, R.K. (2010). Openness and Technological Innovation in East Asia, Have They Increased the Demand for Skills? Policy Research Working Paper 5272, The World Bank.

Chen, C.H. (1996). Regional Determinants of Foreign Direct Investment in Mainland China. Journal of Economic Studies, vol.23, No.2, pp.18-30.

Chen, T.J. (1992). Determinants of Taiwan's Foreign Direct Investment: the Case of a Newly Industrializing Country. J Dev, Econ, vol.39, no.2, pp: 397-407.

Chen, Y. (2009). Agglomeration and Location of Foreign Direct Investment: The Case of China. China Economic Review, vol.20, pp: 349-557

Cheng, L.K., and Kwan, Y.K. (2000). What Are the Determinants of the Location of Foreign Direct Investment? The Chinese Experience. Journal of Intentional Economics, vol.51, pp.379-400.

Chiang, Y.H. (2010). FDI Location Choice at Provincial China. International Review of Business Research Papers, vol.6, no.5, pp: 274-292.

Coughlin, C., and Segev, E. (1999). Foreign Direct Investment in China: A Spatial Econometric Study. The Federal Bank of St.Louis Working Paper.

Dunning, J.H. (1980). Toward an Eclectic Theory of International Production: Some Empirical Tests. Journal of International Business Studies, vol.11, pp.9-13.

Dunning, J.H. (1988). Explaining International Production. London: Allen and Unwin.

Dunning, J.H. (1993). Multinational Enterprises and the Global Economy. New York: Addison-Wesley.

Dunning, J.H., and Lundan, S.M. (2008). Multinational Enterprises and the Global Economy. UK, Edward Elgar Publishing limited.

Fleisher, B., Li, HZ., \& Zhao, M.Q. (2010). Human Capital, Economic Growth, and Regional Inequality in China. Journal of Development economics, vol.92, pp.215-231.

Gu, WS., Awokuse, T.O., \& Yuan, Y. (2008). The Contribution of Foreign Direct Investment to China's Export.

Heckman, J.J. (2005). China's Human Capital Environment. China Economic Review, vol.16, pp.50-70.

Huang, YS. (2003). Selling China-Foreign Direct Investment during the Reform Era. Cambridge University Press, United Kingdom.

International Standard Industrial Classification of All Economic Activities Revision 4. (2008). Department of Economic and Social Affair, United National, New York.

Javorcik, B.S. (2004). Composition of Foreign Direct Investment and Protection of Intellectual Property Right Myth? Contribution to Economic Analysis \& Policy, vol.3, no.2, article 8.

Lin, FJ. (2010). The Determinants of Foreign Direct Investment in China: The case of Taiwanese firms in the IT Industry. Journal of Business Research, vol.63, pp: 479-785.

Luo, L., Brennan, L., Liu, C., \& Lao. Y. (2008). Factors Influencing FDI Location Choice in China's Inland Areas. China and World Economy, vol.16, no.2, pp.03-108. 
OECD Science, Technology and Industry Scoreboard, 2007, OECD.

OECD Science, Technology and Industry Scoreboard, 2009, OECD.

PECD. (2000). Main determinants and impacts of Foreign Direct Investment on China's Economy, OECD Working Papers on International Investment, OECD publishing.

Performance: Evidence from Disaggregated Sectors, Presentation at the American Agricultural Economics Association annual Meeting, Orlando, July.

Perlitz, M. (1997). Internationales Management. Stuttgart: Lucius \& Elgar.

Sun, HS. (2001). Foreign Direct Investment and Regional Export Performance in China. Journal of Regional Science, vol.41, no.2, pp.317-336.

Sun, HS., and Tipton, F.B. (1998). A Comparative Analysis of the Characteristics of Direct Foreign Investment in China, 1979-1995. The Journal of Developing Areas, vol. 32, pp.159-186.

Sun, HS., Hone. P., \& Doucouliagos, H. (1999). Economic Openness and Technical Efficiency in China: A Case Study of Chinese Manufacturing Industries. The Economics of Transition, vol.7, pp.615-636.

Sun, Q., Tong, W., \& Yu, Q. (2002). Determinants of Foreign Direct Investment across China. Journal of International Money and Finance, vol. 21, pp.79-113.

Tuan, C., \& Ng, L.F.Y. (2004). Manufacturing agglomeration as incentives to Asian FDI in China after WTO. Journal of Asian Economics, vol.15, pp: 673-693.

Wei, KL, Yao, SJ., \& Liu, A. (2009). Foreign Direct Investment and Regional Inequality in China. Review of Development Economics, vol.13, no.4, pp.778-791.

Zhao, G., \& Zhang, Z. (2010). Uncovering the Relationship between FDI, Human Capital and Technological Progress in Chinese High-technology Industries. China \& World Economy, vol.18, no.1, pp: 82-98.

Zhao, T. (2004). Comparison between Industrial Classification in Chinese National Accounts and International standard Industrial Classification for All Economic Activities, $8^{\text {th }}$ OECD-NBS Workshop on National Account, Paris.

Zhao, Z., \& Zhang, K. (2010). FDI and Industrial Productivity in China: Evidence from Panel Data in 2001-2006. Review of Development Economics, vol.14, no.3, pp: 656-665.

\section{Notes}

Note 1. The aggregate total FDI for individual regions are collected from provincial statistical yearbook, which the total is not the same as China Statistical yearbook or UNCTAD database.

Note 2. UNCTAD FDI database

Note 3. Primary Sector includes: Agriculture, Forestry, Animal Husbandry and Fishery; Secondary Sector includes: Mining and Processing, Production and Supply of Electricity, Gas and Water, and Construction; Tertiary sector includes: Transport, Storage and Post, Information Transmission, Computer Services and Software, Wholesale and Retail Trades, Hotel and Catering Services, Financial Intermediation, Real Estate, Leasing and Business Service, Scientific Research, Technical Service and Geologic Prospecting, Management of Water Conservancy, Environment and Public Facilities, Services to Households and Other Services, Education, Health, Social Security and Social Welfare, Culture, Sports and Entertainment, Public Management and Social Organisations, International Organisations.

Note 4. There are large share of exporting miscellaneous goods, which could be part of the manufacture good.

Note 5. There are 12 provinces in coastal region: Beijing, Tianjin, Hebei, Liaoning, Shanhai, Jiangsu, Zhejiang, Fujian, Shandong, Guangdong, Guangxi, and Hainan; 9 provinces in Inner region: Shanxi, Jilin, Heilongjiang, Anhui, Jiangxi, Henan, Hubei, Inner Mongolia, and Hunan; and 10 in western region: Chongqing, Sichuan, Guizhou, Yunnan, Shaanxi, Gansu, Qinghai, Ningxia, Xinjiang and Tibet (not included in this research)

Note 6. The four Special Economic Zones are Shenzhen, Zhuhai, Shantou and Xiamen

Note 7. Tianjin, Shanghai, Dalian, Qinhuangdao, Yatan, Qingdao, Lianyugang, Nantong, Ningbo, Wenzhou, Fuzhou, Guangzhou, Zhanjiang and Beihai

Note 8. Using the corresponding year's exchange rate to convert CNY to USD. In 1988,1 USD=3.7221Yuan; in 2007:1 USD= 7.604 Yuan.

Note 9. Using the corresponding year's exchange rate to convert CNY to USD. In 1988,1 USD=3.7221Yuan; in 2007:1 USD= 7.604 Yuan.

Note 10. Population aged above 6 years old.

Note 11. Due to data availability, there is no disaggregated form of FDI inflow into manufacture industry, in this research, foreign equity will be used to represent the contribution of foreign capital in different industries. 


\section{Appendix}

1. Based on OECD's Technology classification of manufacturing industries, it classified manufacturing industries into 4 classes: High-technology industries, medium-high-technology industries, medium-low0technology industries and low-technology industries. High-technology industries include Pharmaceuticals; office, accounting and computing machinery; radio, television and communication equipment; medical, precision and optical instruments and aircraft and spacecraft. Medium-high technology industries include electrical machinery and apparatus, n.e.c.; motor vehicles, trailers and semi-trailers; chemicals excluding pharmaceuticals; railroad equipment and transport equipment, n.e.c., and machinery and equipment, n.e.c. The medium-low-technology industries include building ad repairing of ships and boats; rubber and plastic products; coke, refined petroleum products and nuclear fuel; other non-metallic mineral products and basic metals and fabricated metal products. The low-technology industries include manufacturing, n.e.c.; recycling; wood, pulp, paper, paper products, printing and publishing; food products, beverages and tobacco; textiles, textile products, leather and footwear. In this research, the author grouped the manufacturing industries into two sub-classes, which are high-technology which included high and medium-high-technology industries, and low-technology includes medium-low and low-technology industries. In this paper, manufacturing industry are classified into two-subsample, which are medium to high-technology industries (High-technology + medium-high-technology) and low to medium-technology industries (Low-technology + medium-low-technology)

2. The primary industry refers to agriculture, forestry, animal husbandry and fishery. The secondary industry refers to mining, manufacturing, production and supply of electricity, water and gas, and construction. The tertiary industry refers to all other economic activities not included in primary or secondary industries, including traffic, transportation, storage and post, information transmission, computer services and software, wholesale and retail trades, hotel and catering services, Financial Intermediation, real estate, leasing and business services, scientific research, technical services and geological prospecting, management of water conservancy, environment and public facilities, services to households and other services, education, health, social security and social welfare, culture, sports and entertainment, public management and social organisation, and international organisations. The current census does not include international organisations.

3. Some FDI data for what represented in the statistical yearbook reflect distortion. This is the case with the so-called 'round-tripping investment' between China and Hong Kong, which aims to take advantage of incentives offered to foreign investment. Estimates by UNCTAD suggest that found-tripping might account for $25-40 \%$ of the inward FDI stock in China, where in addition to Hong Kong; the larger estimate includes investment that is routed through the tax havens of British Virgin Island, Bermuda, Panama and the Cayman islands. (Dunning 2008 and UNCTAD)

4. Data availability: There are 3 sources provide FDI inflow into China at national level, they are China statistical yearbook, UNCTAD database, and sum up FDI into 31 individual provincial Statistical yearbook to get total FDI inflow into China. The major problem with provincial and regional analysis of FDI inflow is the three sources provided different amount of FDI inflow, (i.e. the sum up of individual provincial FDI inflow has the largest amount of FDI compare to China Statistical yearbook and UNCTAD database.) China statistical yearbook only provides Utilised FDI from 1987 to 2004. as this study is a regional analysis, the author is using the sum up of individual provinces to get the regional FDI inflow data, which may provide more meaningful and accurate analysis.

Table 2 indicates how foreign investors (which include those from Hong Kong, Taiwan, Macao(HTM) and other foreign investors) contribute to manufacturing industry (Note 11). In low technology class, such as textiles, garment and leather production, foreign equity represents 33.68 per cent of national total in 2002, while medium-to-high-technology manufacturing sub-classes represents only 28.85 per cent. However, with adopted foreign capital, management know-how, trained labour, and technology spill-over effect, China possesses the capacity to adopt high-technology-intensive manufacturing sectors, especially within the chemicals, machinery, transport equipment, electronics and telecommunication industries. 
Table 1. Distribution of FDI in Different Sectors, 1997-2008

\begin{tabular}{|c|c|c|c|c|c|c|c|}
\hline & National Total & Primary & & Secondary & & Tertiary & \\
\hline & USD million & USD million & $\%$ & USD million & $\%$ & USD million & $\%$ \\
\hline 1997 & 45257.0 & 672.6 & 1.4 & 32569.9 & 72.0 & 10518.2 & 23.2 \\
\hline 1998 & 45462.8 & 623.8 & 1.4 & 31327.5 & 68.9 & 12365.4 & 27.2 \\
\hline 1999 & 40318.7 & 710.2 & 1.8 & 27779.8 & 68.9 & 10863.7 & 26.9 \\
\hline 2000 & 40714.8 & 675.9 & 1.7 & 29575.0 & 73.4 & 9011.1 & 22.3 \\
\hline 2001 & 46877.6 & 898.7 & 1.9 & 35675.5 & 76.1 & 10129.9 & 21.6 \\
\hline 2002 & 52742.9 & 1027.6 & 1.9 & 39464.9 & 74.8 & 10929.3 & 20.7 \\
\hline 2003 & 53504.7 & 1000.8 & 1.9 & 39179.2 & 73.2 & 11073.6 & 20.7 \\
\hline 2004 & 60630.0 & 1114.3 & 1.8 & 45463.1 & 75.0 & 14052.6 & 23.2 \\
\hline 2005 & 60324.7 & 718.3 & 1.2 & 44492.4 & 73.8 & 14914.0 & 24.7 \\
\hline 2006 & 63020.6 & 599.5 & 1.0 & 42506.6 & 67.4 & 19914.6 & 31.6 \\
\hline 2007 & 74767.9 & 924.1 & 1.2 & 42861.1 & 57.3 & 30982.8 & 41.4 \\
\hline 2008 & 92395.4 & 1191.0 & 1.3 & 53256.2 & 57.6 & 37948.2 & 41.1 \\
\hline Average & 56334.75 & 842.7 & 1.5 & 388679.3 & 69.9 & 16058.6 & 27.1 \\
\hline
\end{tabular}

Source: China's Statistical Yearbook, 1998-2009 China

Table 2. China's Export Fact Sheets 1980-2008 (USD 100 million)

\begin{tabular}{|c|c|c|c|c|c|c|c|c|c|c|c|c|c|}
\hline \multirow{3}{*}{ Year } & \multirow{3}{*}{\begin{tabular}{|l|} 
Total \\
\\
USD $\$ 100 \mathrm{~m}$ \\
\end{tabular}} & \multicolumn{12}{|c|}{ Manufactured Goods } \\
\hline & & \multicolumn{2}{|c|}{ Sub-total } & \multicolumn{2}{|c|}{$\begin{array}{l}\text { Chemicals and } \\
\text { Related } \\
\text { Products }\end{array}$} & \multicolumn{2}{|c|}{$\begin{array}{l}\text { Light and Textile } \\
\text { Industrial } \\
\text { Products, Rubber } \\
\text { Products, } \\
\text { Minerals } \\
\text { Metallurgical } \\
\text { Products }\end{array}$} & \multicolumn{2}{|c|}{$\begin{array}{l}\text { Machinery and } \\
\text { Transport } \\
\text { Equipment }\end{array}$} & \multicolumn{2}{|c|}{$\begin{array}{l}\text { Miscellaneous } \\
\text { Product }\end{array}$} & \multicolumn{2}{|c|}{$\begin{array}{l}\text { Products Not } \\
\text { Otherwise } \\
\text { Classified }\end{array}$} \\
\hline & & $\$ 100 \mathrm{~m}$ & $\%$ & $\$ 100 \mathrm{~m}$ & $\%$ & $\$ 100 \mathrm{~m}$ & $\%$ & $\$ 100 \mathrm{~m}$ & $\%$ & $\$ 100 \mathrm{~m}$ & $\%$ & $\$ 100 \mathrm{~m}$ & $\%$ \\
\hline 1980 & 181.2 & 90.1 & 49.7 & 11.2 & 12.4 & 40.0 & 44.4 & 8.4 & 9.4 & 28.4 & 31.5 & 2.1 & 2.3 \\
\hline 1985 & 273.5 & 135.2 & 49.4 & 13.6 & 10.0 & 44.9 & 33.2 & 7.7 & 5.7 & 34.9 & 25.8 & 34.1 & 25.2 \\
\hline 1990 & 620.9 & 462.1 & 74.4 & 37.3 & 8.1 & 125.7 & 27.2 & 55.9 & 12.1 & 126.9 & 27.5 & 116.3 & 25.2 \\
\hline 1991 & 719.1 & 557.0 & 77.5 & 38.2 & 6.9 & 144.6 & 26.0 & 71.5 & 12.8 & 166.2 & 29.8 & 136.6 & 24.5 \\
\hline 1992 & 849.4 & 679.4 & 80.0 & 43.5 & 6.4 & 161.4 & 23.8 & 132.2 & 19.5 & 342.3 & 50.4 & & \\
\hline 1993 & 917.4 & 750.8 & 81.8 & 46.2 & 6.2 & 163.9 & 21.8 & 152.8 & 20.4 & 387.8 & 51.7 & & \\
\hline 1994 & 1210.1 & 1013.0 & 83.7 & 62.4 & 6.1 & 232.2 & 22.9 & 219.0 & 21.6 & 499.4 & 49.3 & 0.1 & 0.0 \\
\hline 1995 & 1487.8 & 1273.0 & 85.6 & 90.9 & 7.1 & 322.4 & 25.3 & 314.1 & 24.7 & 545.5 & 42.9 & 0.1 & 0.0 \\
\hline 1996 & 1510.5 & 1291.2 & 85.5 & 88.8 & 6.9 & 285.0 & 22.1 & 353.1 & 27.3 & 564.2 & 43.7 & 0.1 & 0.0 \\
\hline 1997 & 1827.9 & 1588.4 & 86.9 & 102.3 & 6.4 & 344.3 & 21.7 & 437.1 & 27.5 & 704.7 & 44.4 & 0.1 & 0.0 \\
\hline 1998 & 1837.1 & 1632.2 & 88.9 & 103.2 & 6.3 & 324.8 & 19.9 & 502.2 & 30.8 & 702.0 & 43.0 & 0.1 & 0.0 \\
\hline 1999 & 1949.3 & 1749.9 & 89.8 & 103.7 & 5.9 & 332.6 & 19.0 & 588.4 & 33.6 & 725.1 & 41.4 & 0.1 & 0.0 \\
\hline 2000 & 2492.0 & 2237.4 & 89.8 & 121.0 & 5.4 & 425.5 & 19.0 & 826.0 & 36.9 & 862.8 & 38.6 & 2.2 & 0.1 \\
\hline 2001 & 2661.0 & 2397.6 & 90.1 & 133.5 & 5.6 & 438.1 & 18.3 & 949.0 & 39.6 & 871.1 & 36.3 & 5.8 & 0.2 \\
\hline 2002 & 3256.0 & 2970.6 & 91.2 & 153.3 & 5.2 & 529.6 & 17.8 & 1269.8 & 42.7 & 1011.5 & 34.1 & 6.5 & 0.2 \\
\hline 2003 & 4382.3 & 4034.2 & 92.1 & 195.8 & 4.9 & 690.2 & 17.1 & 1877.7 & 46.5 & 126.9 & 31.3 & 9.6 & 0.2 \\
\hline 2004 & 5933.3 & 5527.8 & 93.2 & 263.6 & 4.8 & 1006.45 & 18.2 & 2682.6 & 48.5 & 1564.0 & 28.3 & 11.1 & 0.2 \\
\hline 2005 & 7619.5 & 7129.2 & 93.6 & 357.7 & 5.0 & 1291.2 & 18.1 & 3522.3 & 49.4 & 1941.8 & 27.2 & 16.1 & 0.2 \\
\hline 2006 & 9689.4 & 9160.2 & 94.5 & 445.3 & 4.9 & 1748.2 & 19.1 & 4563.4 & 49.8 & 2380.1 & 26.0 & 23.2 & 0.3 \\
\hline 2007 & 12177.8 & 11562.7 & 95.0 & 603.2 & 5.2 & 2198.8 & 19.0 & 5770.5 & 49.9 & 2968.4 & 25.7 & 21.8 & 0.2 \\
\hline 2008 & 14306.9 & 13527.4 & 94.6 & 793.5 & 5.9 & 2623.9 & 19.4 & 6733.3 & 49.8 & 3359.6 & 24.8 & 17.1 & 0.1 \\
\hline
\end{tabular}

Source: China Statistical Yearbook, 1996 - 2009 
Table 3. FDI and its Role in the Chinese Economy in 1995, 2003 and 2008

\begin{tabular}{|l|l|l|l|}
\hline Year & Total National Export & \multicolumn{3}{|l|}{ Total Export from Foreign } & Funded Enterprises \\
\hline & USD\$ 100 million & USD\$ 100 million & $\%$ \\
\hline 1995 & 1487.80 & 468.76 & 31.51 \\
\hline 2003 & 4382.28 & 2403.38 & 54.84 \\
\hline 2008 & 14306.93 & 7904.93 & 55.25 \\
\hline \multicolumn{2}{|l|}{ Source: Various Provincial Statistical Yearbook } \\
\hline
\end{tabular}

Table 4. Determinants of FDI in the OLI framework

\begin{tabular}{|c|c|c|c|}
\hline $\begin{array}{l}\text { Types of } \\
\text { International } \\
\text { Production }\end{array}$ & $\begin{array}{l}\text { Ownership advantages (they } \\
\text { 'why' of MNE activity }\end{array}$ & $\begin{array}{l}\text { Location advantages (the } \\
\text { 'Where' of production) }\end{array}$ & $\begin{array}{l}\text { Internalisation advantages (the } \\
\text { 'how' of involvement }\end{array}$ \\
\hline $\begin{array}{l}\text { Natural } \\
\text { Resource } \\
\text { Seeking }\end{array}$ & $\begin{array}{l}\text { Capital, technology, access to } \\
\text { markets; complementary } \\
\text { assets; size and bargaining } \\
\text { strengths }\end{array}$ & $\begin{array}{l}\text { Possession of natural resources, } \\
\text { and related transport and } \\
\text { communications infrastructure; } \\
\text { tax and other incentives }\end{array}$ & $\begin{array}{l}\text { To ensure stability of suppliers } \\
\text { at right price; to control } \\
\text { markets }\end{array}$ \\
\hline Market Seeking & $\begin{array}{l}\text { Capital, technology, } \\
\text { information, management and } \\
\text { organisation skills; surplus } \\
\text { R\&D and other capacity; } \\
\text { economies of scale; ability to } \\
\text { generate brand loyalty }\end{array}$ & $\begin{array}{l}\text { Material and labour cost; } \\
\text { market size and characteristics; } \\
\text { government policy (e.g. with } \\
\text { respect to regulations and to } \\
\text { import controls, investment } \\
\text { incentives, etc.) }\end{array}$ & $\begin{array}{l}\text { A desire to reduce transaction } \\
\text { or information costs, buyer } \\
\text { ignorance or uncertainty; to } \\
\text { protect property rights }\end{array}$ \\
\hline $\begin{array}{l}\text { Efficiency } \\
\text { Seeking } \\
\text { (a) of products } \\
\text { (b) of processes }\end{array}$ & $\begin{array}{l}\text { As above, but also access to } \\
\text { markets; economies of scope, } \\
\text { geographical diversification } \\
\text { and/or clustering, and } \\
\text { international sourcing of } \\
\text { inputs }\end{array}$ & $\begin{array}{l}\text { (a) Economies of product or } \\
\text { process specialisation and } \\
\text { concentration } \\
\text { (b) Low Labour cost; incentive } \\
\text { to local production by host } \\
\text { governments; a favourable } \\
\text { business environment }\end{array}$ & $\begin{array}{l}\text { (a) As foe second category, plus } \\
\text { gains from economies of } \\
\text { common governance } \\
\text { (b) The economies of vertical } \\
\text { integration and horizontal } \\
\text { diversification }\end{array}$ \\
\hline $\begin{array}{l}\text { Strategic asset } \\
\text { seeking }\end{array}$ & $\begin{array}{l}\text { Any of first three that offer } \\
\text { opportunities for synergy with } \\
\text { existing assets }\end{array}$ & $\begin{array}{l}\text { Any of first three that offer } \\
\text { technology, organisational, and } \\
\text { other assets in which firm is } \\
\text { deficient }\end{array}$ & $\begin{array}{l}\text { Economies of common } \\
\text { governance; improved } \\
\text { competitive or strategic } \\
\text { advantages; to reduce or spread } \\
\text { risk }\end{array}$ \\
\hline
\end{tabular}

Source: Dunning (2008), p.105, Table 4.1 
Table 5. Industry Characteristic of FIEs in Chinese Manufacturing Industries, 1995 Vs 2008 (\%)

\begin{tabular}{|c|c|c|c|c|c|c|c|}
\hline & \multirow{2}{*}{ Manufacturing industry } & \multicolumn{2}{|c|}{$\begin{array}{c}\text { Share of FIE sales } \\
\text { of all sales }\end{array}$} & \multicolumn{2}{|c|}{$\begin{array}{c}\text { Share of FIE exports } \\
\text { of FIE sales }\end{array}$} & \multicolumn{2}{|c|}{$\begin{array}{c}\text { Share of FIE export } \\
\text { of all export }\end{array}$} \\
\hline & & 1995 & 2008 & 1995 & 2008 & 1995 & 2008 \\
\hline \multirow{21}{*}{ Low tech } & Food processing & 21.2 & 13.8 & 24.5 & 3.7 & 57.5 & 51.4 \\
\hline & Food manufacturing & 30.5 & 11.7 & 16.6 & 4.3 & 38.7 & 49.1 \\
\hline & Beverage manufacturing & 26.2 & 4.7 & 4.5 & 1.1 & 37.8 & 56.1 \\
\hline & Tobacco processing & 0.6 & 1.5 & 17.3 & 0.0 & 2.5 & 0.3 \\
\hline & Textile industry & 17.9 & 40.4 & 48.6 & 9.2 & 28.6 & 47.2 \\
\hline & Garments and foodwear & 50.8 & 52.7 & 71.7 & 22.2 & 60.5 & 61.7 \\
\hline & Leathers and related products & 54.1 & 53.5 & 73.6 & 25.5 & 73.2 & 68.8 \\
\hline & Timber processing and related products & 57.7 & 35.5 & 31.5 & 5.4 & 58.7 & 26.1 \\
\hline & Furniture manufacturing & 75.1 & 61.7 & 45.8 & 24.6 & 75.1 & 66.6 \\
\hline & Papermarking and paper products & 53.4 & 17.5 & 20.8 & 5.9 & 53.4 & 83.5 \\
\hline & Printing and recored pressing & 79.4 & 28.3 & 19.8 & 8.0 & 79.4 & 79.9 \\
\hline & Culture, educational and sports articles & 69 & 72.4 & 81.3 & 41.1 & 69 & 72.5 \\
\hline & Petroleum processing and product & 1.4 & 7.5 & 21.8 & 1.0 & 8.5 & 59.9 \\
\hline & Chemical fibers & 12.7 & 10.4 & 26.3 & 3.2 & 41.5 & 37.1 \\
\hline & Rubber products & 25 & 38.6 & 39.7 & 15.1 & 53.3 & 65.0 \\
\hline & Plastic products & 33.1 & 42.3 & 42.6 & 21.7 & 77.2 & 76.5 \\
\hline & Nonmetal mineral products & 11.4 & 21.6 & 21.4 & 3.7 & 38.9 & 51.7 \\
\hline & Smelting and pressing of ferrous metals & 6.2 & 8.7 & 9.3 & 1.2 & 6.3 & 18.0 \\
\hline & Smelting and pressing of nonferrous metals & 12.5 & 16.0 & 18 & 2.5 & 24.4 & 44.2 \\
\hline & Metal proeucts & 26.6 & 43.9 & 47.2 & 13.6 & 61.1 & 64.6 \\
\hline & Average & 33.2 & 29.1 & 34.1 & 10.6 & 47.3 & 54.0 \\
\hline \multirow{9}{*}{ High tech } & Chemical materials and products & 12.6 & 15.6 & 22.7 & 4.2 & 31.6 & 55.5 \\
\hline & Medical and pharmaceutical products & 18.3 & 13.8 & 16.9 & 3.7 & 21.9 & 37.0 \\
\hline & Ordinaty machinery manufacturing & 14.5 & 30.6 & 21.9 & 7.8 & 30.6 & 54.4 \\
\hline & Special purpose equipment & 9.0 & 28.8 & 27.9 & 7.8 & 35.5 & 57.9 \\
\hline & Transportation equipment & 25.2 & 17.4 & 7.6 & 7.8 & 30.4 & 50.6 \\
\hline & Electric equipment and machinery & 21.8 & 44.8 & 34.3 & 15.8 & 58.3 & 68.3 \\
\hline & Electronic and telecommunications & 60.8 & 76.7 & 59.1 & 62.5 & 94.5 & 91.9 \\
\hline & Instruments & 38.8 & 65.6 & 51.2 & 37.7 & 71.8 & 87.3 \\
\hline & Average & 25.1 & 36.7 & 30.2 & 18.4 & 46.8 & 62.9 \\
\hline
\end{tabular}

Source: Third Industrial Census (1997) and China Industrial Economic Statistics Yearbook, 2009

Table 6. Regional Economic Indicators 2008

\begin{tabular}{|l|l|l|l|l|l|}
\hline \multicolumn{2}{|l|}{ Population } & \multicolumn{1}{l|}{ GDP } & GDP of national Total & \multicolumn{1}{l|}{ GDP per Capita } \\
\hline & \multicolumn{1}{|l|}{10000 person } & $\%$ & RMB billion & & Yuan/person/year \\
\hline National Total & 129973 & & 33421.18 & & 25713.94 \\
\hline Coastal & 56241 & 43.27 & 20171.50 & 60.36 & 35866.19 \\
\hline Inner & 44439 & 34.19 & 8796.11 & 26.32 & 19793.66 \\
\hline Western & 29293 & 22.54 & 4453.57 & 13.33 & 15203.53 \\
\hline \multicolumn{5}{|l}{ Source: China Statistical Yearbook 2009 } \\
\hline
\end{tabular}

Table 7. Technological Infrastructure Factsheet, 1990, 2000 and 2008

\begin{tabular}{|l|l|l|l|l|l|l|l|l|l|}
\hline & \multicolumn{9}{|l|}{$\begin{array}{l}\text { 2000 } \\
\end{array}$} \\
\hline & $\begin{array}{l}\text { R\&D } \\
\text { Spending }\end{array}$ & $\begin{array}{l}\% \text { of } \\
\text { regional } \\
\text { GDP }\end{array}$ & $\begin{array}{l}\text { Number of } \\
\text { University }\end{array}$ & $\begin{array}{l}\text { R\&D } \\
\text { Spending }\end{array}$ & $\begin{array}{l}\text { \% of } \\
\text { regional } \\
\text { GDP }\end{array}$ & $\begin{array}{l}\text { Number of } \\
\text { University }\end{array}$ & $\begin{array}{l}\text { R\&D } \\
\text { Spending }\end{array}$ & $\begin{array}{l}\% \text { of } \\
\text { regional } \\
\text { GDP }\end{array}$ & $\begin{array}{l}\text { Number } \\
\text { of } \\
\text { University }\end{array}$ \\
\hline & RMB billion & $\%$ & unit & RMB billion & $\%$ & unit & RMB billion & $\%$ & unit \\
\hline Coastal & 1001.8 & 1.03 & 515 & 5949.20 & 1.12 & 497 & 20171.53 & 1.69 & 1074 \\
\hline Inner & 547.92 & 0.48 & 348 & 2554.28 & 0.56 & 343 & 8796.11 & 0.92 & 754 \\
\hline Western & 311.30 & 0.72 & 209 & 1335.16 & 0.80 & 197 & 4453.57 & 0.90 & 429 \\
\hline Source: China Statistical Yearbook, $1991-2009$ & & & & & & \\
\hline
\end{tabular}




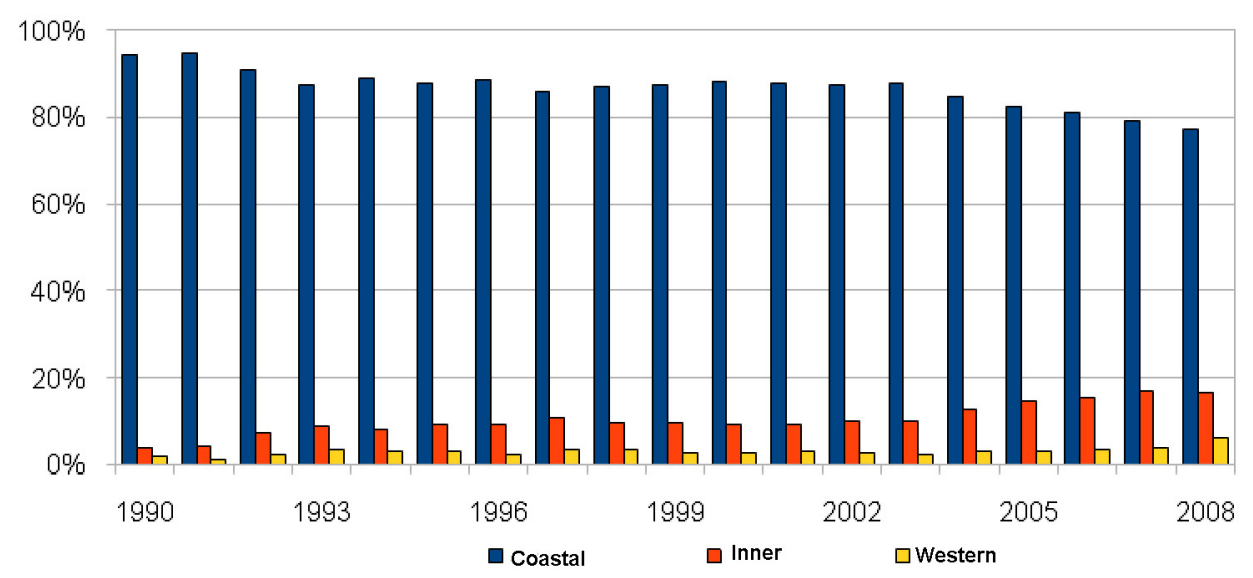

Figure 1. Regional distribution of FDI inflow into China, 1986-2008\% Source: China Statistical Yearbook, 1996-2009
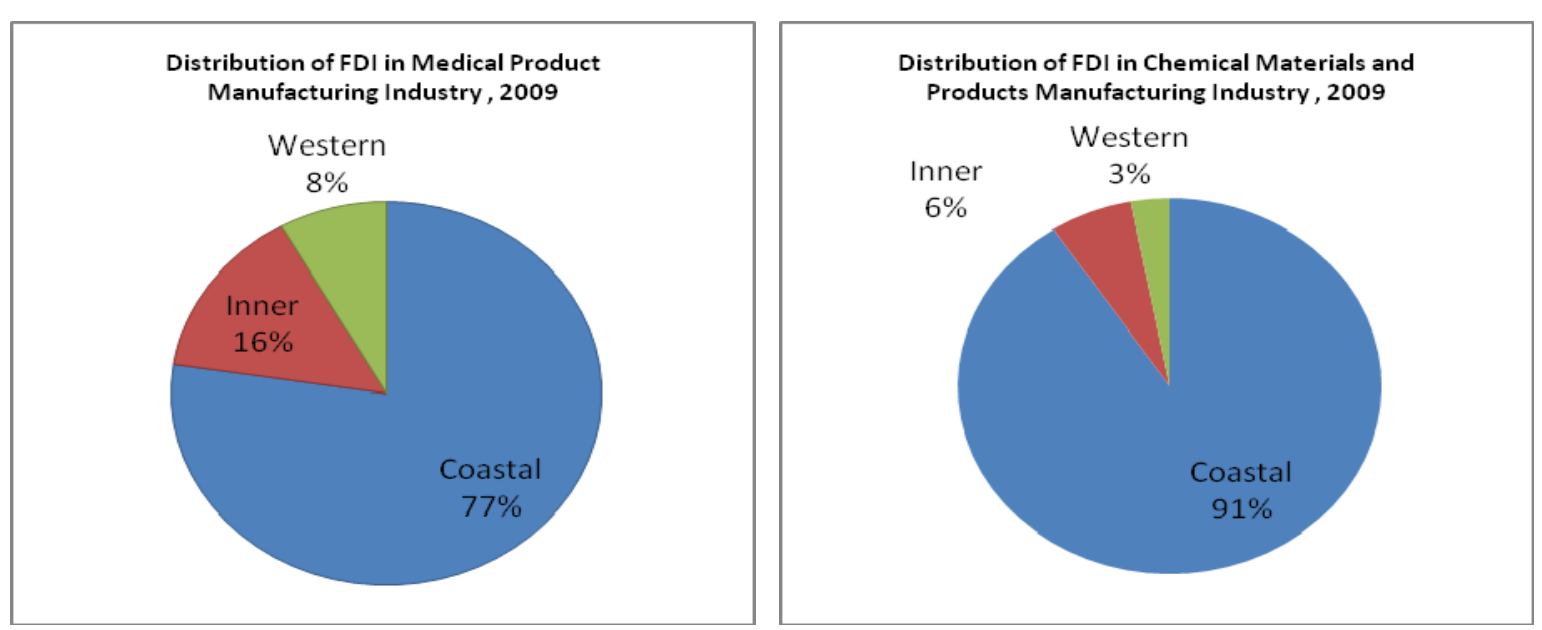

Figure 2. Distribution of FDI in Some High Technology Manufacturing Industry, 2009

Source: China Statistical Yearbook, 1996-2009
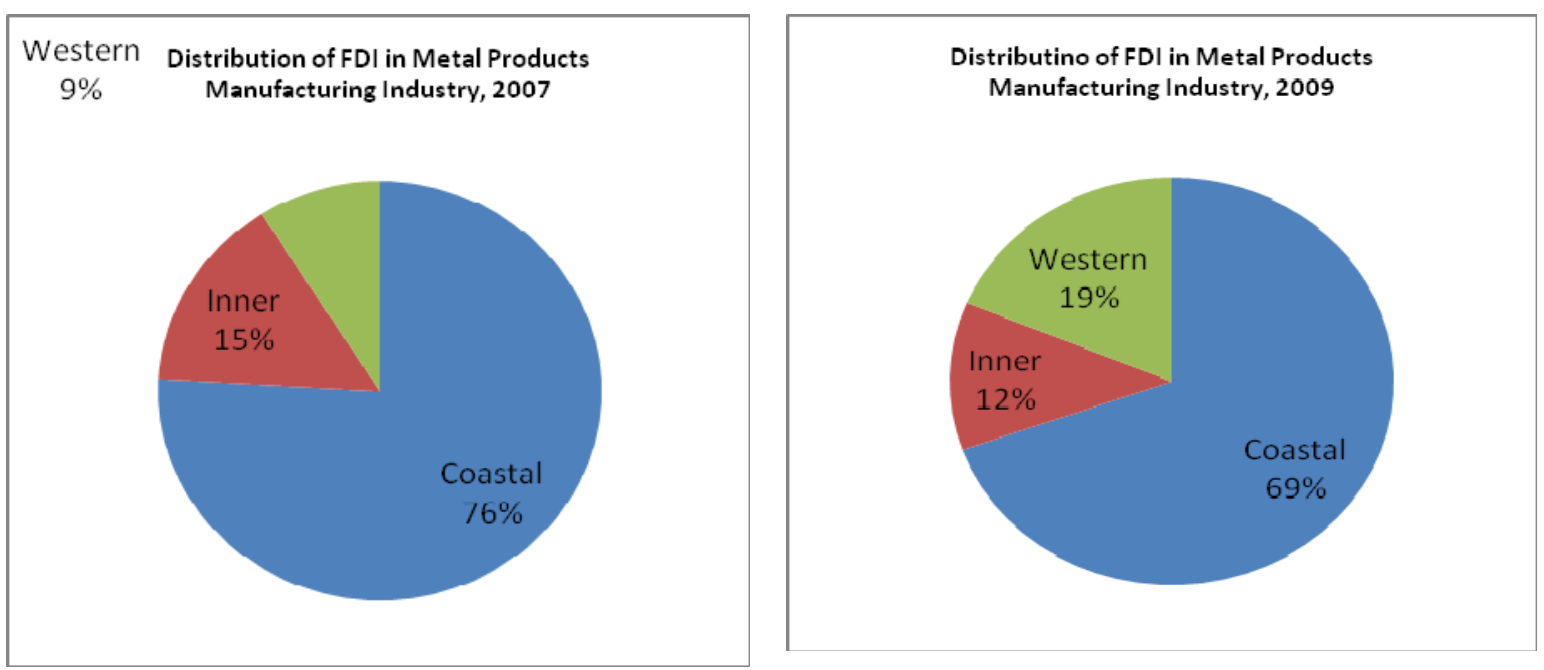

Figure 3. Distribution of FDI in Metal Products Manufacturing Industry, 2007 Vs 2009

Source: Ministry of Commerce People's Republic of China, 2010 


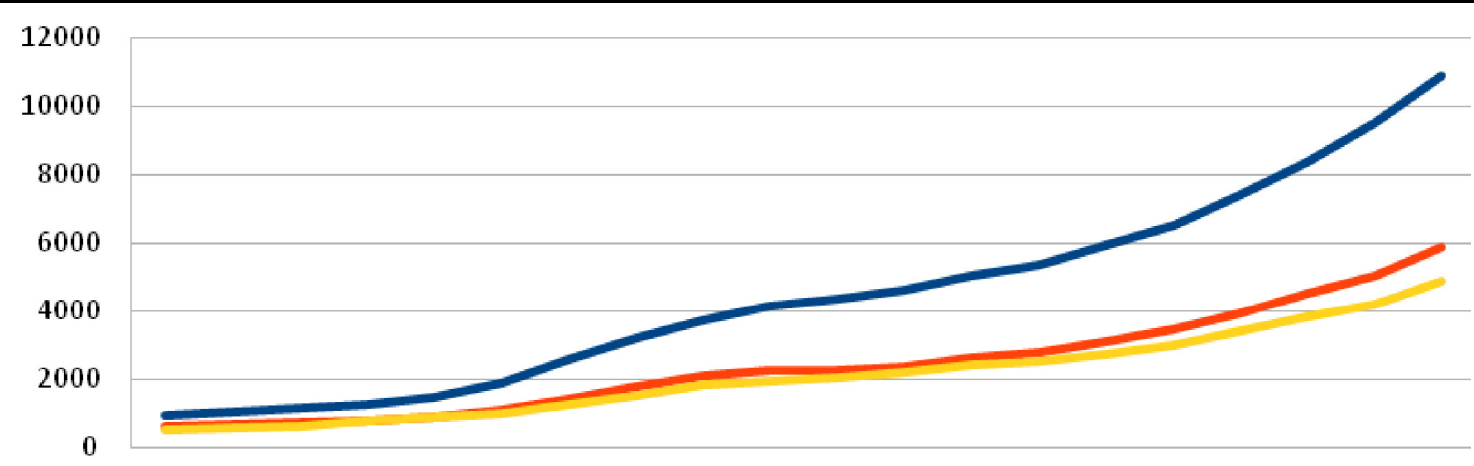

19881989199019911992199319941995199619971998199920002001200220032004200520062007

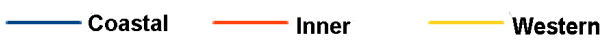

Figure 4. Per Capita Consumption in Coastal, Inner and Western Regions, 1988-2007

(Yuan/per person/year) Source: MOFTEC Database

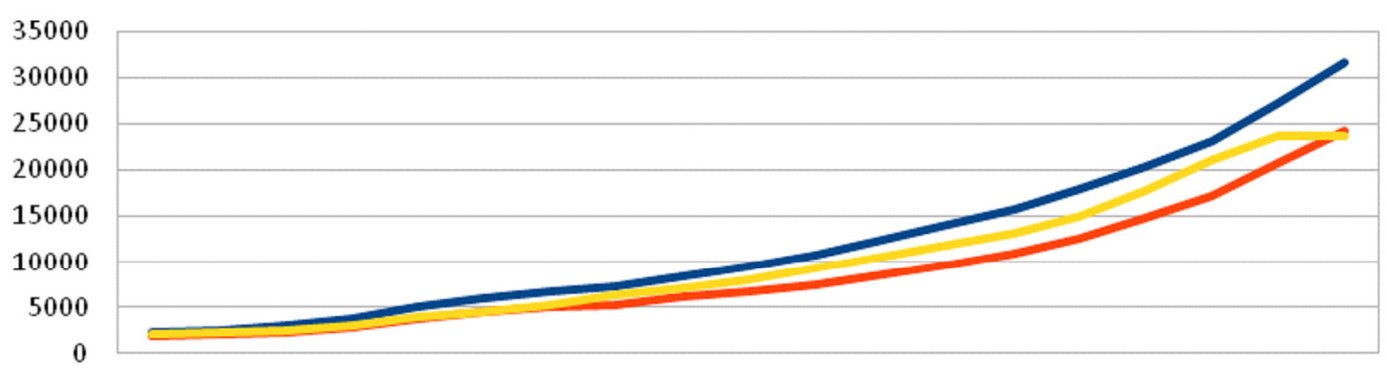

1990199119921993199419951996199719981999200020012002200320042005200620072008

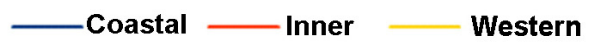

Figure 5. Average Wage of Coastal Inner, and Western Regions in China, 1990-2008 (RMB Yuan)

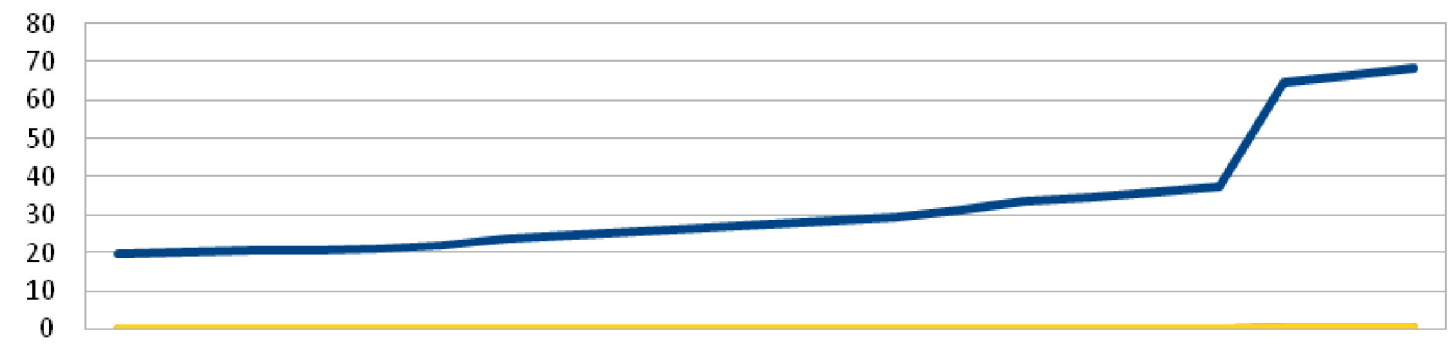

198819891990199119921993199419951996199719981999200020012002200320042005200620072008

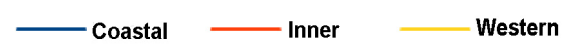

Figure 6. Length of High-way per km2 in Coastal, Inner and Western regions, 1988-2008

Source: China Statistical Yearbook, 1996-2009 